\title{
Indian Almond Tree (Terminalia catappa Linn.) as Herbal Biomedicine in Aquaculture Industry
}

\author{
Mahadevi $^{1 *}$, S. Felix ${ }^{1}$, K. Ravaneswaran ${ }^{1}$, P. Yuvarajan ${ }^{1}$ and K.S. Monica ${ }^{2}$ \\ ${ }^{1}$ Tamil Nadu Dr. J. Jayalalithaa Fisheries University, Nagapattinam, Tamil Nadu, India \\ ${ }^{2}$ College of Fisheries Mangalore, Karnataka, India \\ *Corresponding author
}

Keywords

Indian almond tree, Herbal-

biomedicine,

Antimicrobial,

Anti-parasitic, and

Antifungal

Article Info

Accepted:

17 June 2019

Available Online:

10 July 2019

\section{A B S T R A C T}

Aquaculture is growing drastically over the years with intensification. On the other hand intensification increased the stress, occurrence of diseases, introduction of new pathogens and application of the synthetic chemical substances to overcome these problems. Recently adoption of herbal medicine in aquaculture practices is becoming the trend due its advantages over the chemical substances. Plants are storehouses and sources of safer and cheaper chemicals. Numerous herbal plants have been identified for its anti-microbial, antifungal, anti-parasitic, growth promotion, appetite stimulation, immunostimulation and stress reducer properties. Indian almond tree (Terminalia catappa Linn.) is one among them. Tannin is the major chemical component of $T$. catappa which exhibits the antimicrobial property. The reports on use of Indian almond leaves as herbal biomedicine have been reviewed in the present article. The extensive work need to be done to optimize the dose and duration of treatment against the most common pathogens.

\section{Introduction}

Aquaculture is intensifying substantially in recent years, along with the high production there are several constrains in the intensification such as crowding which leads to stress and ends up with the outbreak of disease and crop failure. To control these disease outbreaks farmers are increasingly using the chemical components such as
Hormones, antibiotics and vitamins. Generally these chemical substances are introduced into culture systems without proper knowledge of dose, application methods, mode of action and degradation capacity. This may cause the side effects to culture animal, residual accumulation in the edible tissue and drug resistance in the pathogens. Adverse effects of antibiotics made increased the interest of consumer to 
natural products (Fauci 1993). Plants are storehouses and sources of safer and cheaper chemicals (Chanu et al., 2012). The herbs have been used in the treatment of human diseases and for revitalizing body systems during almost all ancient civilizations (Aftab and Sial 1999). The herbal medicine is considered to be safe and economical.

Preparations of herbal extract is most important factor in disease control during which active ingredients such as antioxidant, antimicrobial, antistress, growth promotion, appetite stimulation, tonic and immunostimulation, and aphrodisiac properties should not be lost (Chanu et al., 2012). In general herbal properties of the plants are related to the availability and activity of compound s such as alkaloids, flavonoids, pigments, phenolics, terpenoids, steroids and essential oils.

Indian almond tree (Terminalia catappa Linn.) is a large tree, which can reach up to $30 \mathrm{~m}$ height with a thick broad trunk; the leaves cluster toward the end of the branches (Whistler, 1992). Leaves and barks of Indian almond tree are widely used in human as a traditional medicine to treat hepatitis, dermatosis, oral infections, and intestinal ailments in children and adults. Decoction of the leaves is used to treat indigestion, furred tongue, bronchitis and tuberculosis (Whistler, 1992).

Recent reports shows that extracts of leaves and barks has properties such as (1) Anticancer (2) Anti-oxidation (3) antiinflammation (4) antifungal properties (againt Pythium ultimum, Rhizoctonia solani, Sclerotium rolfsii, and Aspergillus fumigates) (5) and antibacterial properties (against; Staphylococcus epidermidis, S.aureus, Bacillus cereus, B. subtilis, and Pseudomonas aeruginosa (Nantarika Chansueland Nongnut Assawawongkasem, 2008).

\section{Chemical composition of the Indian almond leaves}

The chemical compositions of this plant contains tannins (punicalagin, punicalin, terflavin $\mathrm{A}$ and $\mathrm{B}$, tergallagin, tercatain, chebulagic acid, geranin, granatin $\mathrm{B}$, corilagin), flavanoids, isovitexin, vitexin, isoorientin, rutin and triterpenoiods (ursolic acid, $2 \alpha, 3 \beta, 23$-trihydroxyurs-12-en-28 oic acid) (Ahmed et al., 2005).

Tannin is a polyphenolic compound consisting of antibacterial properties (Chung et al., 1998).

\section{Indian almond leaves as Herbal medicine}

Indian almond leaves has been locally claimed to be a wound healing substance for Siamese fighting fish hurt after matches (Liu et al., 1996). Chansue et al., (2004) opined that the leaves have a potential to use as an alternative treatment for chemical substances and antibiotics.

\section{Anti-microbial}

The antibacterial active principles of the herbals may lyse the cell wall, block the protein synthesis and DNA synthesis, inhibit the enzyme secretions and interfere with the signalling mechanism of quorum sensing pathway (Citarasu, 2009). The crude ethanol extract from the leaves of Indian almond has been observed to be active against Staphylococcus aureus with a minimum inhibitory concentration of $512 \mu \mathrm{g} / \mathrm{ml}$ (Burapadaja, 1997).

Indian almond, Terminalia catappa, extract is an alternative antibacterial remedy against tilapia bacterial pathogen A. hydrophila. The growth of two strains of A. hydrophila was inhibited at a concentration of $0.5 \mathrm{mg} \mathrm{ml} / \mathrm{L}$ (Chitmanat et al., 2005). 


\section{Anti-parasitic}

Indian almond (Terminalia catappa) have been reported (Chitmanat et al., 2005) to treat tilapia fish ectoparasites viz., Trichodina sp. The infected fish become lethargic generate excessive mucus and become off feed eventually which results in considerable deaths. Chitmanat et al., (2005) observed that the crude extracts of Indian almond at 800 $\mathrm{mg} / \mathrm{L}$ significantly $(\mathrm{P}<0.05)$ eliminated the Trichodina sp. infections in tilapia (average weight $3.62 \pm 0.06 \mathrm{~g}$ each). According to these investigators Indian almond at $800 \mathrm{ppm}$ was effective in eradication of Trichodina sp. from tilapia after 2-day treatment.

The leaf extracts can eliminate Zoothamnium spp. infection of black tiger post larva shrimp within 24 hours after exposure (Watchariya et $a l ., 2004)$ and also has potential to decrease the number of Gyrodactylus and Dactylogyrus infection of gold fish (Chansue and Tangtrongpiros, 2005).

\section{Anti-fungal}

The herbal extracts involve the fungal cell wall lysis, altering the permeability, affecting the metabolism and RNA and protein synthesis which leads to death (Citarasu, 2010). Chitmanat et al., (2005) showed that Indian almond leaves (Terminalia catappa) extract reduced the fungal infection in tilapia eggs. The crude extracts of $T$. catappa had in vitro antifungal properties against Pythium ultimum, Rhizoctonia solani, Sclerotium rolfsii, and Aspergillus fumigatus (Goun et al., 2003).

The limited study has been done on application of Indian almond leaves as herbal biomedicine. The extensive works on the test trials and toxicity study is needed in order to popularize and commercialize the herbal biomedicine.
Application of herbal biomedicine is a possible way to reduce the use of synthetic chemical substances and to overcome its constraints such as side effects, residual issues and drug resistivity. Indian almond leaves have the properties of herbal biomedicine, the extensive work need to be done to optimize the dose and duration of treatment against the most common pathogens.

\section{References}

Aftab, K. and Sial, A. A. 1999. Phytomedicine: New and old approach. Hamdard Medicus, 42(2): 11-15.

Ahmed S M, Swamy V, Dhanapal P G R and Chandrashekara V M. Anti-Diabetic, 2005. Activity of Terminalia catappa Linn. Leaf Extracts in Alloxan-Induced Diabetic Rats. Iranian J Pharmacol \& Therapeutics. 4(1): 36-39.

Burapadaja, S. 1997. Research report entitled antimicrobial activities derived from Indian almond (Terminalia catappa). Dept. of Pharmaceutical Technology, Faculty of Pharmacy, Chiang Mai University. $14 \mathrm{p}$.

Chansue N, Mataderm T, Suilasuta A. 2004. Preliminary study of Effects of Dried Indian Almond Terminalia catappa leaf on ultrastuctural morphology of scale in Siamese fighting fish (Betta splendens). Proceeding of Thai Herbal: Opportunities and Alternative way for Agriculture-Animal industries. Siam city Hotel. Bangkok, Thailand, January 15-16: 140-144.

Chansue N, Tangtrongpiros J. 2005. Effect of Dried Indian almond Leaf (Terminalia catappa) on Monogenean Parasite of Gold Fish (Carassius auratus). Proceeding of the $4^{\text {th }}$ Chulalongkorn University Veterinary Annual Conference. 60 Veterinary Anniversary Building, Chulalongkorn University, Faculty of Veterinary Science, 
Bangkok, Thailand, February 15 (2005), 55-56.

Chitmanat C, Tongdonmuan K, Nunsong W. 2005. The use of crude extract from traditional medicinal plants to eliminate Tricodina sp. In tilapia (Oreochromis niliticus) fingerlings. Songklanakarin $J$. Sci. Technol. 27(Suppl.1): 359-364.

Chung KT, Lu Z, Chou MW. 1998. Mechanism of inhibition of tannic acid and related compounds on the growth of intestinal bacteria. Food and Chemical Toxicology. 36(12): 1053-1060.

Citarasu Thavasimuthu, 2010. Herbal biomedicines: a new opportunity for aquaculture industry, Aquacult Int, 18:403-414, DOI 10.1007/s10499-0099253-7.

Fauci, A.S. 1993. Multifactorial nature of human immunodeficiency virus: implications for therapy. Science 262: 1011-1018.

Goun E, Cunningham G, Chu D, Nguyen C, Miles D. 2003. Antibacterial and antifungal activity of Indonesian ethnomedical plants. Fitoterapia. 74(6): 592-596.

Liu T., Ho L., Tsai Y., Chiang S., Chao T., Li
J. and Chi C. 1996. Modification of mitomycin C-induced clastogenicity by Terminalia catappa $\mathrm{L}$. in vitro and in vivo. Cancer Letters 105: 113-118.

Nantarika Chansue1 and Nongnut Assawawongkasem, 2008. The in vitro Antibacterial Activity and Ornamental Fish Toxicity of the Water Extract of Indian Almond Leaves (Terminalia catappa Linn.) KKU Vet J. 18(1): 3645.

Thongam Ibemcha Chanu, Arun Sharma, S. Dam Roy, Ajit Keshav Chaudhuri and Pradyut Biswas. 2012. Herbal Biomedicine - an Alternative to Synthetic Chemicals in Aquaculture Feed in Asia, world aquaculture: 14-16. Watchariya P, Surapon W, Nontawit A. 2004. Efficiency of some Herbals for eliminate Zoothamnium sp. and toxicity on Penaeus monodon Fabricius. The 5th National conference of marine shrimp. Miracle Grand Convention Hotel. Bangkok. BIOTEC. March 29-30, 2004.

Whistler A. 1992. Polynesian Herbal Medicine. Hong Kong: Everbest Printing Co., Ltd.

\section{How to cite this article:}

Mahadevi, S. Felix, K. Ravaneswaran, P. Yuvarajan and Monica, K.S. 2019. Indian Almond Tree (Terminalia catappa Linn.) as Herbal Biomedicine in Aquaculture Industry. Int.J.Curr.Microbiol.App.Sci. 8(07): 2406-2409. doi: https://doi.org/10.20546/ijcmas.2019.807.295 